\title{
The Empowerment of Small Enterprises in Construction Sector for Government Procurement of Goods and Services: Mandatory Study of Role and Risk Mustofa Kamal ${ }^{1}$ and John Elim ${ }^{2}$ \\ ${ }^{1}$ Pusdiklatwas BPKP dan FH Unida, Ciawi, Bogor ${ }^{2}$ Universitas Persada Indonesia, Y.A.I, Jakarta, Indonesia
} kamalopek.bpkp@gmail.com

\begin{abstract}
This study aims to investigate the empowerment of small enterprises in construction sector and the risks since the issuance of Perpres No.16 Year 2018 and Permen PUPR No 7 Year 2019. The accuracy of the procurement and the development of small-medium enterprise role have been parts of the objectives of government procurement. Then, the policy states that government should give opportunities to small enterprises. Qualitative study was conducted using the approach of applied law research. Literature study and observation on the stake holders were done. The results showed that small enterprises in construction sector played more roles with the procurement package up to $R p$ 10,000,000,000.00 (ten billion rupiah). However, the implementation in 2018 showed that the role of small enterprises declined compared to the previous year, the participation of small enterprises in construction sector was still low compared to non-small enterprises. Besides that, the small enterprises that received the procurement package were prone to criteria violation of small enterprises as in UU No. 20 Year 2008 about micro, small and medium enterprises (MSME). The identified risk was that the small enterprises received the package for small enterprises in construction sector. This risk should be maintained and handled by procurement agents through effective qualification verification, by government instances that issue the construction permit by developing the potency of the small enterprises to level up, and government instances through association of construction enterprises by cooperating in building good governance in the management of construction procurement.

Keywords: small enterprises, empowerment, risks, good governance

JEL : G38

DOI : : 10.24002/kinerja.v22i2.2765
\end{abstract}

Received : 10/28/2019 Reviewed: 01/29/2020 Final Version: 02/20/2020 


\section{INTRODUCTION}

Micro, small, and medium enterprises (MSME) have proven to be durable during the economic crisis in Indonesia from 1997 to 1998. Even, after the crisis in 2012, MSME can absorb 85 million until 107 million labors. The number of MSME grows and becomes the majority up to $56,534,592$ units or $99.99 \%$ out of $56,539,560$ units (Suci, 2017).

The growth of MSME needs supports of government policy, business associations, universities and the relevant agencies (Hamid \& Susilo, 2011). Therefore, the government always endeavors to support the development of MSME and strengthens the role of MSME through regulation and policy.

The mandate to develop MSME comprehensively, optimally, and sustainably has been stated in Constitution of Indonesian Republic No 20 year 2008 about MSME (which later is called UU 20/2008). Moreover, Presidential Regulation of Indonesian Republic No. 16 year 2018 (abbreviated as P16/2018) about government procurement of goods and services or pengadaan barang dan jasa pemerintah (abbreviated as PBJP) explicitly states several objectives of PBJP. One of which is to develop the role and the number of MSME. To reach the goals of PBJP, there are some PBJP policies in article 5 of P16/2018 that must be implemented by PBJP practitioners. The three of the PBJP policies are to give opportunities to MSME, to use information and communication technology and electronic transaction, and to develop PBJP e-marketplace.

Regarding the objectives, P16/2018 mandates that package value of procurement of goods/construction works/other services that needs to be reserved for small enterprises (article 65 act 4 P16/2018), is as much as Rp $2,500,000,000.00$ (two billion five hundred million rupiah). The maximum limit of this package values aligns with one of the criteria of small enterprises as stated in UU 20/2008, article 6 act 2 b stating that the enterprises make a yearly sale from Rp 300,000,000.00 (three hundred million rupiah) up to Rp 2,500,000,000.00 (two billion and five hundred million rupiah) at the maximum.

The other mandate is from Public Works and Public Housing (PUPR) Ministry of Indonesian Republic No 07/PRT/M/2019 about Standard and Guidance of Construction Service Procurement for the provider, which later is abbreviated as Permen PUPR 7/2019. This mandate states the opportunity of small enterprises in construction sector is to have the maximum value of construction procurement package for small enterprises and to have Self-Estimated Price (HPS) as much as Rp 10,000,000,000.00 (ten billion rupiah).

From the practitioners' perspective, there is an empirical evidence about the development of MSME through analysis of Strength, Weakness, Opportunity and Threat (SWOT). The results show the strategy to acknowledge the internal weaknesses like when the SMSEs do not have knowledge about e-commerce, and the external threat like when the buyers do not trust the e-marketplace (Syuhada, 2013), market penetration strategy (Alyas\& Rakib M, 2017), cost advantage strategy and differentiation strategy (Abdillah, dkk, 2017), growth strategy 
(Ariani\&Utomo, 2017), capital development (Agnefa, 2018) and shopping optimization as the internal strength to development the business (Kamal, 2019).

From the description of small enterprises in P16/2018 and Permen PUPR $7 / 2019$ and some strategy to develop MSME, five questions emerge in this study as the following:

1. How is small enterprise development in PBJP like?

2. How are small enterprises of construction sector in PBJP like?

3. What risks are PBJP agencies and SMSE in construction sector going to deal with the difference of maximum value of construction procurement package in P16/2018 and in Permen PUPR 7/2019?

4. What strategy should be implemented by PBJP agencies and government instances to handle the risks?

5. What strategy should be implemented by small enterprises in construction sector to increase the participation on PBJP?

Therefore, the aims of this study are to see the mandatory role and the portrait of small enterprises in construction sector and its risks. Later, this paper will be written with the order of literature review, research methodology, discussion and conclusion.

\section{LITERATURE REVIEW}

\subsection{Definition, Criteria, and Mandate of Small Enterprise Development}

There are some regulations stating the definition and criteria and the role of small enterprises (later called UK) in PBJP, such as: UU 20/2008 and P16/2018. The definition of small enterprises is a productive economic business that is run independently by personal or business entities, which is not a subsidiary nor a branch company belonging to or a part of medium and big enterprises that fulfil the criteria of small enterprises as stated in regulations of micro, small, and medium enterprises. The criteria of UK (article 6 act 2 UU 20/2008) are as follows:

1. Have net worth more than Rp 50,000,00.00 (fifty million rupiah) up to at the maximum of Rp 500,000,000.00 (five hundred million) excluding the land and the business premises; or

2. Make a yearly sale more than $\mathrm{Rp} 300,000,000.00$ (three hundred million rupiah) up to the maximum of Rp 2,500,000,000.00 (two billion five hundred million rupiah)

UU 20/2008 article 1 states that MSME development is an effort done by the state government, regional government, business sector, and the people in synergy to set growth climate and develop business so that MSME can grow to be a durable and independent business. The business climate is a condition set by the state government and the regional government to develop MSME in synergy by making the regulations and policies in many aspect of economic lives so MSME gets partialities, assurance, opportunities, protection, and supports to do business. Meanwhile, development is an effort done by the state government and the regional government, business sector, and the people to develop MSME by giving 
facility, consultation, guidance, and strengthening assistance to grow and to increase the capability and the competitiveness of MSME.

Growing the business climate for MSME also needs to be done. Article 7 UU 20/2008 act 1 and 2 has given the authority to state government, regional government, business sector, and the people. The state government and the regional government grow the business climate by making regulation and policies that include the aspects of funding, facilities and infrastructure, business information, partnership, business permit, business opportunities, promotion, and institutional support. On the other hand, the business sector and the people play a role to actively support the growth of business climate.

\subsection{Empowerment of MSME in Previous Studies}

The empowerment of MSME also needs to be done by the MSMEs themselves. One way to do the development is by using SWOT analysis. SWOT analysis is done by identifying the weaknesses, the chances, and the challenges (BPKP, 2014). Zahfran (2017) states that there are two main steps in SWOT analysis that is to analyze the four main components of SWOT analysis and to make strategy based on SWOT matrix.

There are some studies concerning the empowerment of MSME that have been conducted by some researchers. Alyas and Rakib M (2017) investigate the strategy of MSMEs development to strengthen the people economics in business of Maros Bread in Maros Municipality. The result shows that marketing product and marketing strategy, and intensive market penetration can develop business by improving promotion, quality, and product innovation of Roti Maros.

Besides that, Ariani and Utomo (2017) analyse the development strategy and competitiveness to deal with the free trading of ASEAN Economic Community (AEC) in 2015, on a small enterprise in Tarakan, North Kalimantan. The result of the study shows that growth strategy can be used to maintain the quality of the raw material, qualified product permit, affordable price and human resource improvement.

In the other place, Hamid and Susilo (2011) analyze the development strategy of MSME in the province of Yogyakarta (DIY). The results of the study shows that the development of MSME should not be done by MSME themselves, but should also be supported by the government policy and all stake holders such as business association, universities, and relevant agencies in the municipalities/city in DIY. In the same province, Agnefa (2018) studies the use of SWOT analysis as a strategy to develop MSME Warmindo Wala Weleu. The study shows that the strategy to develop the capital is to apply accounting to manage the funding and to develop the marketing by promotion of products.

In e-market, Syuhada (2013) identifies the internal weaknesses of MSME, such as the lack of knowledge to e-commerce and the limited technology infrastructure. The analysis of external threat shows that buyers are not confident and they needs profile information and the business verification. 


\section{METHODOLOGY}

This study is a qualitative research adopting the approach of applied law research. According to Sugiyono, qualitative research is a research that is used to study the natural condition of the object where the researcher is the key instrument (Gunawan, 2013).

The sources of the data used in this study are primary legal material, secondary legal material, and tertiary legal material. The primary law material is the law material that has legally-binding forces in the form of laws and regulations. The secondary legal material is the legal material that is closely related to the primary legal material, such as scientific writing and journal. Meanwhile, the tertiary legal material is complementary to the secondary legal material. The tertiary legal material includes the law dictionary, index and bibliography (Suteki dan Taufani, 2018).

According to Abdulkadir Muhammad (as cited in Suteki and Taufani, 2018), there are two stages of applied law research; the stage of normative law study and the study of law implementation to reach the objectives that have been set. The result of the implementation will create the understanding of the realization whether or not the normative law has been implemented properly. The scope of the normative law is the normative law concerning the MSME development, roles of small business, construction procurement, and the openness of public information for the stake holders of MSME. The objects of this study are mandate, roles, and the risks of small enterprises in construction sector in Indonesia.

The data source or the primary legal material includes the constitution, government regulation, presidential regulation and minister regulation. The secondary law material is scientific research and journals related the best practice of MSME development. Observation was done by gathering information from the website of the institution or organization related to the research object, which is also used as complementary law material. The research process is conducted with the steps as seen in the following Figure 1:

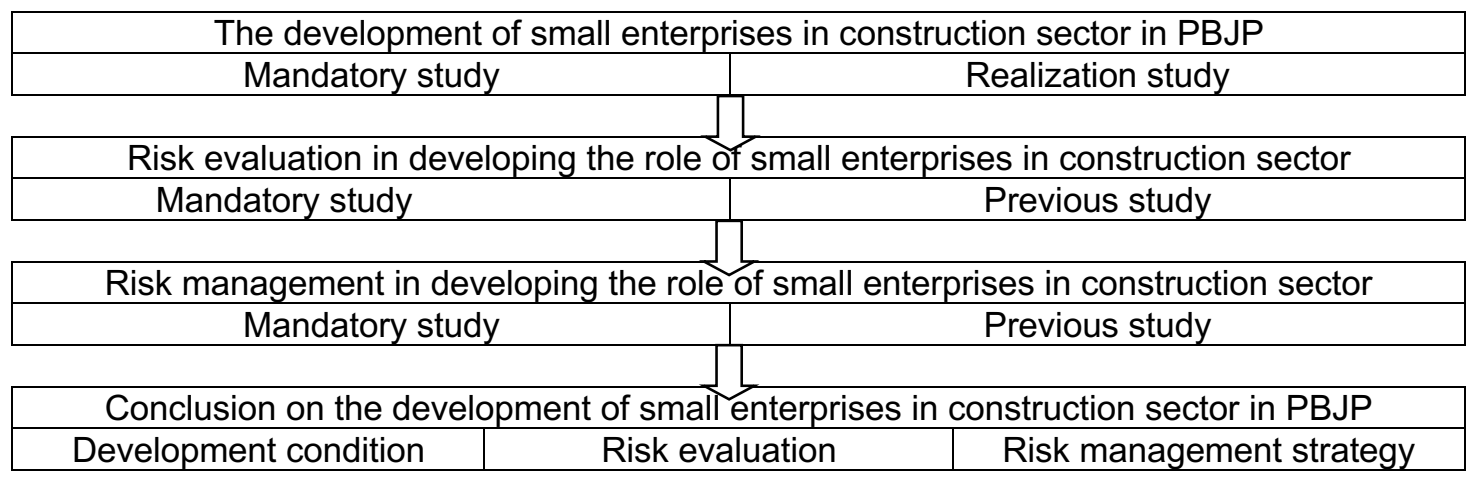

Figure 1. Research Process 


\section{RESULT AND DISCUSSION}

\subsection{Mandate of Small Enterprise Role in PBJP and Good Governance}

Small enterprises have a strategic role in the management of government procurement of goods and services. Explicitly, Perpres 16/2018 states that one of the objectives of PBJP is to improve the role of MSME (article 4 letter c). Meanwhile, the procurement package of goods/construction work/other reserved services for small business, in line with article 65 act 4 , is as much as $R p$ $2,500,000,000.00$ (two billion and five hundred million rupiah). This mandate can be seen on Table 1.

Table 1. Mandatory Development of MSME role and e-marketplace in PBJP

\begin{tabular}{|c|c|c|c|c|c|}
\hline \multirow[b]{2}{*}{ No. } & \multirow[b]{2}{*}{ Mandatory } & \multicolumn{4}{|c|}{ PBJP Management } \\
\hline & & $\begin{array}{c}\text { Objectiv } \\
\mathrm{e}\end{array}$ & Policy & $\begin{array}{c}\text { Planning, Preparation, \& } \\
\text { Implementation }\end{array}$ & Supervision \\
\hline 1 & MSME Role & $\begin{array}{l}\text { The } \\
\text { improve } \\
\text { ment of } \\
\text { MSME } \\
\text { roles }\end{array}$ & $\begin{array}{c}\text { Give } \\
\text { opportunities to } \\
\text { MSME (article } 5 \\
\text { letter } \mathrm{g} \text { ), } \\
\text { Procurement } \\
\text { package } \leq \mathrm{Rp} \\
2,5 \text { billion } \\
\text { (article } 65 \text { act } 4 \text { ) }\end{array}$ & $\begin{array}{l}\text { 1. Electronic Procurement } \\
\text { System (article 71), } \\
\text { 2. Electronic Procurement } \\
\text { Service by UKPBJ (article } \\
75 \text { letter b), } \\
\text { 3. e-catalogue (Article 72) } \\
\text { 4. e-nurchasing (Article 1 }\end{array}$ & $\begin{array}{c}\text { K/L/PD must } \\
\text { supervise the } \\
\text { improvement of } \\
\text { MSME role (Article } \\
76 \text { letter e) }\end{array}$ \\
\hline 2 & e-marketplace & $\begin{array}{l}\text { (article } 4 \\
\text { letter c) }\end{array}$ & $\begin{array}{l}\text { The use of IT \& } \\
\text { e-marketplace } \\
\text { (article } 5 \text { letters } \\
\text { d, e) }\end{array}$ & $\begin{array}{l}\text { number } 35 \text { ) } \\
\text { e-catalogue, online store, } \\
\text { e-tendering (article 70) }\end{array}$ & $\begin{array}{l}\text { LKPP supervises } \\
\text { SPSE (Article } 70 \\
\text { letter } 3 \text { ) }\end{array}$ \\
\hline
\end{tabular}

Source: summarized from P16/2018

The information in the table explains that the mandate to develop MSME in PBJP is more vigorous. Even more, the MSME development can be optimized through mandate of PBJP e-marketplace.

Regarding the mandate, Permen PUPR 7/2019, issued on 20 March 2019, states to give opportunity of the package with HPS up to Rp10,000,000,000.00 (ten billion rupiah) for construction work providers that are categorized as small enterprises. If the mandate of P16/2018 is compared to Permen PUPR 7/2019 that was issued a year later, there is broader opportunity or increase of roles of small business in construction sector.

Information in the table and the aforementioned explanation show that government has made efforts to create a conducive climate for the improvements of MSME role in the procurement management. This condition aligns with the mandate to develop MSME as stated in UU 20/2008 with the concept of good governance (Figure 2). 
Development is a synergic endeavor done by the state government, regional government, business sector, and the people to create the climate and to develop MSME so they can be durable and independent business (UU 20/2008). The concept of good governance is a comprehensive concept that synergize three pillars, that is government, people, and business sector (Kamal \&Elim, 2018). The three pillars of good governance should synergize in growing the business climate and developing the MSME in order to reach the three objectives of MSME development. The government has created the business climate in the form of mandate of MSME role and e-marketplace in PBJP.

\subsection{Government'sEndeavor to Improve the Role of Small Enterprises in PBJP}

The government has given opportunities to the small enterprises to take a role in procurement process for five years or since 2014-2018 in the form of "yearly average of UK role proportion" in the budget ceiling as much as $26.84 \%$ and in the procurement package as much as $74.45 \%$.

However, looking at the trend of the last five years, it appears that the role of UK in 2018 budgeting is still lower than 2017. The proportion of budget ceiling for the UK role decreases for $1.43 \%$ or as much as $24.72 \%$ in 2017 to be $23.29 \%$ in 2018. Similarly, the procurement package decreases $1.43 \%$ or as much as $76.30 \%$ in 2017 to be $75.77 \%$ in 2018 (details on appendix 1)

\subsection{Participation of Small Enterprises in e-tendering in PBJP}

The realization of small enterprises role in e-tendering for the period of five times years or from 2014-2018 in the form of "yearly average of UK realization proportion" in e-tendering, is as much as $20.35 \%$ in budget ceiling and $64.91 \%$ in procurement package (details on appendix 2).

Looking at the trend from the last five years, it appears that the realization of UK role in e-tendering in the budget ceiling increases from the budget year 2017 to 2018 , from $16.82 \%$ to $17.64 \%$, or increases for $0.82 \%$. However, looking at the realization of UK in e-tendering in the procurement package, it shows that the budget decreases from 2017 to 2018, from $63.68 \%$ to be $60.62 \%$, or $3.06 \%$ decrease.

\subsection{Participation of Small Enterprises in Construction Sector in PBJP}

In 2018, there were 81,126 small business units and 27,402 units of non-small business in construction sector that are registered in Sistem Informasi Kinerja Penyedia or SIKAP (LKPP, 2019). If the number of construction units registered in SIKAP is compared to the population, it can be seen that the level of participation of the small business in construction sector in 2018 is as much as $62.04 \%$ or still under the level of non-small business participation as $91.94 \%$ (See Table 2). 
Table 2. Number of Construction Business

\begin{tabular}{|c|r|r|r|r|r|}
\hline \multirow{2}{*}{\begin{tabular}{c} 
Scale of $\begin{array}{c}\text { Construction } \\
\text { Business }\end{array}$ \\
\cline { 2 - 5 }
\end{tabular}} & \multicolumn{2}{|c|}{ Population } & \multicolumn{2}{c|}{$\begin{array}{c}\text { Registered in } \\
\text { SIKAP }\end{array}$} & $\begin{array}{c}\text { \% registered in } \\
\text { SIKAP to the } \\
\text { Population }\end{array}$ \\
\cline { 2 - 5 } Small Business & 130,771 & 81.44 & 81,126 & 74.75 & 62.04 \\
\hline Non-small business: & & & & & \\
\hline $\begin{array}{c}\text { Medium } \\
\text { Business }\end{array}$ & 28,254 & & & & \\
\hline Big Business & 1,551 & & & & \\
\hline Total of Non-small & 29,805 & 18.56 & 27,402 & 25.25 & \\
\hline Total & 160,576 & 100.00 & 108,528 & 100.00 & \\
\hline
\end{tabular}

Source: Summarized from BPS, 2019 and LKPP, 2019

Then, LKPP (2019) shows that the number of budget ceiling and the etendering procurement package can only show the administration of UK role or the procurement proportion for UK of each type of the procurement, but it does not show the proportion of each type of the construction work procurement for the small business.

The condition can be seen as a signal that in the beginning of the implementation of Perpres 16/2018 mandate, the effectiveness of MSME role improvement in construction sector in PBJP cannot be evaluated. This means in 2018 there is vagueness of work achievement of UK development in construction sector. This condition potentially obstructs the achievement of MSME development goals in construction sector in the coming year.

\subsection{Projection of Roles of Small Business in Construction Sector in PBJP}

Procurement package as much as Rp 10,000,000,000.00 for small business in construction sector (Permen PUPR 7/2019) does not conform with the criteria of small business as stated in act (2) article 6 UU 20/2008 (as in literature review). The study on the relation of the opportunity and small business is as follows:

1. 2 (two) criteria of small business in UU 20/2008 is optional or alternative, with the maximum net worth of Rp $500,000,000.00$ or with yearly turnover of Rp 2,500,000,000.00.

2. The consequence of the 2 (two) criteria: if the provider can fulfill one of the criteria, the provider is still categorized as small business.

3. The 2 (two) criteria and the consequence can be seen deeper through the following Figure 2: 


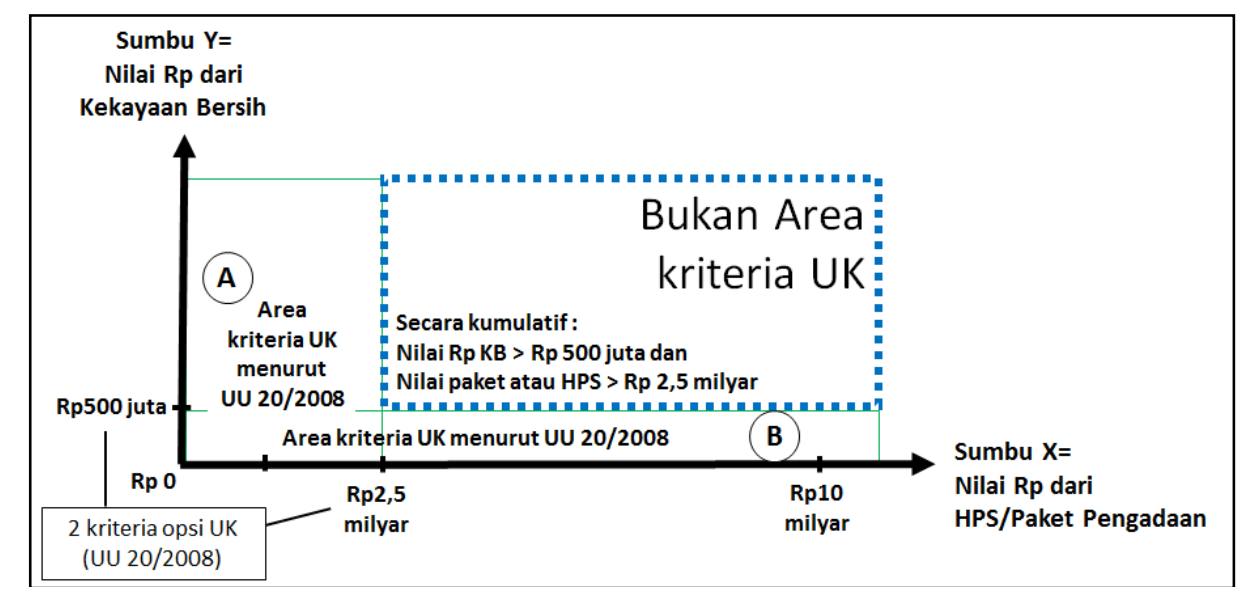

Figure 2. Relation of UK Opportunity and UK Criteria

Source: Summarized from UU 20/2008, Perpres 16/2018, and PermenPUPR $7 / 2019$

Figure 2 shows that the axis $X$ is the PBJP package and axis $Y$ is the net worth of the business actors. The further explanation can be seen in the following examples:

a. If Business $A$ has a net worth of $R p 900,000,000.00$ (or more than $R p$ $500,000,000.00$ ) but the total of the turnover is lower or equals toRp $2,500,000,000.00$, the business is categorized as small business.

b. If Business $B$ gets a contract of $R p 10,000,000,000.00$ (or more than $R p$ $2,500,000,000.00$ ) but the net worth is lower or equals to Rp $500,000,000.00$, the business is categorized as small business.

From here, it can be seen that the businessmen or the company is still categorized as small business under the UK criteria of UU20/2008. The examples show that although the opportunity of small business is broadened in Permen PUPR 7/2019, it is not in line with UU 20/2008. However, the mandate is not contrary against UU 20/2008.

Therefore, it can be concluded that small business (example: Business $B$ ) that gets construction package with HPS $\leq R p 10,000,000,000.00$, after finishing the work, from de facto and de jure perspective, does not conform the criteria of UK in the aspect of "total turnover". The UK criteria that can still be fulfilled by Business B is the "net worth" if the net worth is still $\leq \mathrm{Rp} 500,000,000.00$.

In the era of Permen PUPR 7/2019 implementation or in 2019 and the coming year, the criteria fulfilled by the small business in construction sector (for example UK B) that obtains procurement package with the range of Rp 2.5 billion < HPS value $\leq \mathrm{Rp} 10$ billion is only the net worth.

However, if UK B obtains procurement package with the range of RP 2.5 billion $<$ HPS value $\leq 10$ billion in 2019 and the net worth increases to be $>$ Rp $500,000,000.00$, UK $B$ is then categorized as non-UK. If the business actors earn more than the 2 (two) UK criteria, cumulatively from de facto and de jure perspective the business actors are not categorized as UK. 


\subsection{Risk Evaluation on the Objectives of Small Business Role Improvement in Construction Sector}

PP60/2008 has given mandate concerning the risk evaluation. The chief of governmental institution must conduct risk evaluation that consists of risk identification and risk analysis (PP 60/2008, article13 act 1 and 2), including the risk evaluation for the government procurement of goods and services. The risk evaluation in PBJP is in the form of the evaluation on all aspects or events that can obstruct the achievement of PBJP goals.

The stages of PBJP includes the planning, preparation, implementation, and supervision. The PBJP stages should be implemented to achieve 6 accurate objectives and 7 objectives. One of the six accurate objective is the accuracy of the provider and one of the seven objectives is to improve the role of MSME. The risks should be identified in the PBJP stages.

Organizations can identify risks using prospective and retrospective ways. Prospective way means to identify the risks before they happen but probably happen in the near future. Meanwhile, retrospective ways means to use reports or incidents happening in the past (Nurharyanto, 2010).

The research about risk evaluation prospectively has been conducted by Kamal (2018) with the object of government fraud risk by surveying the training participants. Besides that, Kamal and Tohom (2019) study the fraud risk in procurement prospectively buy surveying online respondents using Google form. Moreover, retrospective study was conducted by Kamal and Elim (2018) concerning the fraud risks coming from the operating method in KPK reports.

When the risks are analyzed prospectively, the implementation of Permen PUPR 7/2019 will possibly make the small business actors to level up if their net worth is over Rp 500 million. Meanwhile, from the provider or the business practitioners, there is a sanction article that can be faced in the era of Permen PUPR 7/2019. Article 40 UU 20/2008 states that:

"Whoever benefits themselves or other people by claiming or using Micro-, small-, and medium-sized business to get facility of funding, business place, business activity or sector, or government procurement of goods and services for micro-, small-, and medium-sized business is convicted with imprisonment of 5 (five) years at the maximum and is fined at the maximum of $R p$ 10,000,000,000.00 (ten billion rupiah)."

After being analyzed normatively on the legal consequence, the provider or small business in construction sector that factually and legally is not categorized as "non-small business" but still claim themselves as small business to get the facility in PBJP is facing the legal risk as abovementioned in article 40 . This potential can be used as source of risk for PBJP actors. The risk is identified as "fake small business". This risk can obstruct the achievement of "accurate provider" and the objective of "improving UK role in construction sector."

In addition, after being analyzed retrospectively, the report of LKPP (2019) and some empirical evidence about MSME development can be used as information source to identify the risk. The risks identified from LKPP (2019) are 
1. The absence of data of construction sector UK role realization for PBJP.

2. The lack of interest in construction sector UK for PBJP

3. From the previous empirical evidence, the identified risks of small business are:

4. The lack of trust and incapability to adapt with technology (Syuhada, 2013),

5. The reluctance to participate and penetrate e-marketplace (Alyas \& Rakib $\mathrm{M}, 2017)$

6. The absence of product legality and human resource development (Ariani \& Utomo, 2017)

7. The lack of support from business association (Hamid \& Susilo, 2011)

8. The lack of information for the market place (Agnefa, 2018)

\subsection{Risk Management in PBJP in the relation with the Objective to Improve UK Role}

Risks need to be handled with control activity. The design of the control should be in line with the risks identified (PP 60/2008). Several control activities can be designed (Table 3).

Table 3. Design of controlling activity based on identified risks

\begin{tabular}{|c|c|c|}
\hline $\begin{array}{l}\text { Identification } \\
\text { Method }\end{array}$ & Identified Risks & Control Activity \\
\hline Prospective & $\begin{array}{l}\text { Fake small business joins the tender } \\
\text { designated for construction UK }\end{array}$ & $\begin{array}{l}\text { Developing effective qualification } \\
\text { verification } \\
\text { Developing advance supervision on } \\
\text { levelling up UK }\end{array}$ \\
\hline Retrospective & $\begin{array}{l}\text { The absence of data of construction } \\
\text { sector UK role realization for PBJP } \\
\text { The lack of interest in construction } \\
\text { UK for PBJP. } \\
\text { The lack of trust and incapability to } \\
\text { adapt with technology } \\
\text { The reluctance to participate and } \\
\text { penetrate e-marketplace } \\
\text { The absence of product legality and } \\
\text { human resource development } \\
\text { The lack of support from business } \\
\text { association. } \\
\text { The lack of information for the market } \\
\text { place }\end{array}$ & $\begin{array}{l}\text { Cooperation between government and } \\
\text { construction small business in the } \\
\text { implementation, such as: } \\
\text { 1. Assisting in technology adaptation } \\
\text { 2. Product legality arrangement } \\
\text { 3. Socializing and developing PBJP } \\
\text { e-marketplace }\end{array}$ \\
\hline
\end{tabular}

Source: Summarized from LKPP (2019) and some previous studies

The table shows that in order to realize the improvement of UK role in construction sector for PBJP, governmental instances should develop some control activities. For example: the identified risk that fake small business joining in tender designated for construction sector UK can be solved by developing an effective qualification verification. Kamal (2010) states that in the best practice overview, the process of verification aims to convince the existence and the legality of 
documents on the qualification form. A working team should verify the data of UK's net worth.

\section{CONCLUSION}

This study aims to figure out the mandate and the portrait of the role development of small business in construction sector and the risk control that can obstruct the achievement of accuracy objective and objective to develop the role of MSME. The result shows that mandatorily the government has optimally given opportunity for improving the role of UK in construction sector for PBJP. However, the portrait of small business procurement development decreased in 2018. Moreover, in construction sector, the UK participation registered in SIKAP is still lower compared to the participation of non-UK.

The next finding is the mandate of Permen PUPR $7 / 2019$ has potential risk identified as fake small construction business joining tender designated for small business. The risk control is to develop effective verification of the qualification and to develop supervision on small business that is potential to level up. The other identified risk is the absence of construction UK role realization. This risk can be handled by building data base. In addition, there are some identified risks coming from the UK condition. This risk can be solved by building cooperation between government, business sector, and small business in construction sector.

This study faces some limitation such as the identified risks have not been analysed so that the value or the score of occurrence level and the level of the impact still remain unknown. The other limitation is the source of small business development realization is only obtained from websites of LKPP and BPS.

\section{REFERENCE}

Abdillah M.B., Hakim R.M.A., Damiri D.M, \& Zahra F. 2017. Analisis Strategi Bisnis Pada UMKM Kerajinan Bambu di Kota Bandung, Jurnal AdBispreneur, 2(3), December, pp.227-242.

Agnefa A.C. 2018. Strategi Pengembangan Usaha Mikro Kecil Menengah Warmindo Wala Weleu Berdasarkan Analisis SWOT. Thesis. Program Studi Pendidikan Ekonomi, Bidang Keahlian Khusus Pendidikan Akuntansi, Universitas Sanata Dharma, Yogyakarta.

Alyas \& Rakib M. 2017. Strategi Pengembangan Usaha Mikro, Kecil dan Menengah dalam Penguatan Ekonomi Kerakyatan (Studi Kasus pada Usaha Roti Maros di Kabupaten Maros). Jurnal Sosio Humaniora, 19(2), July, pp.114-120.

Ariani and Utomo M.N. 2017. Kajian Strategi Pengembangan Usaha Mikro Kecil dan Menengah (UMKM) di Kota Tarakan. Jurnal Organisasi dan Manajemen, 13(2), September, pp. 99-118. 
BPKP. 2014. Analisis Kebijakan Publik. Modul Diklat JFA Penjenjangan Tingkat Madya, Pusdiklatwas BPKP, Bogor.

Gunawan, I. 2013. Metode Penelitian Kualitatif: Teori dan Praktik. PT Bumi Aksara, Jakarta.

Hamid E. S. \& Susilo, Y.S. 2011. Strategi Pengembangan Usaha Mikro Kecil dan Menengah di Provinsi Daerah Istimewa Yogyakarta. Jurnal Ekonomi Pembangunan, 12(1), June, pp. 45-55.

Kamal M. 2010. Pembuktian Kualifikasi yang Efektif: Tinjauan Best Practice, http://pusdiklatwas.bpkp.go.id/asset/files/post/a_38/PEMBUKTIAN_KUALIFIKASI_ YANG_EFEKTIF_tinjauan_best_prctice.pdf [Accessed September 5, 2019].

Kamal, M. 2018. Penilaian Risiko Fraud di Manajemen Pemerintah. Jurnal Liquidity, 7(1), January-June, pp. 27-32.

Kamal, M. \& Elim, J. 2018. Governance Strategy of Government Procurement: Retrospective Case Study. Call for paper in IICAS PGS 2 FIA UI, Hotel Aston Simatupang, Jakarta Selatan.

Kamal, M. \& Tohom, A. 2019. Likelihood Rating of Fraud Risk in Government Procurement, The International Journal of Business Review, June, 2(1).

Kamal, M. 2019. Development Strategy of Village Owned Enterprises Based on Village Expenditure. E-Proceedings and Paper Presentation at The First International Seminar of Widyaiswara Association of Banten Province (IWI Banten), Pandeglang - Banten.

LKPP, 2019, Profil Pengadaan Barang/Jasa Pemerintah T.A. 2018, Deputi Bidang Monitoring-Evaluasi dan Pengembangan Sistem Informasi, Direktorat Perencanaan, Monitoring dan Evaluasi Pengadaan, LKPP https://monevng.lkpp.go.id/themes/slate/dashboard/dokumen/profilpengadaan_2018.pdf, [Accessed September 5, 2019].

Nurharyanto. 2010. Konsep dan Implementasi Risk Assessment, Modul Diklat Sistem Pengendalian Intern Pemerintah (SPIP) Dasar. Pusdiklatwas BPKP, Bogor.

Suteki \& Taufani, G., 2018. Metodologi Penelitian Hukum (Filsafat, Teori dan Praktik), PT Raja Grafindo Persada, Depok.

Suci Y.R. 2017. Perkembangan UMKM (Usaha Mikro Kecil dan Menengah) di indonesia, Jurnal Ilmiah Cano Ekonomos, 6(1). 
Syuhada, A.A. \& Gambetta W. 2013. Online Marketplace for Indonesian Micro Small and Medium Enterprises Based on Social Media, The 4th International Conference on Electrical Engineering and Informatics (ICEEI 2013), Elsevier, Procedia Technology 11, pp. $446-454$.

Zhafran, G.A.R. 2017. Contoh Analisis SWOT | Lengkap Pengertian, Tujuan, Manfaat, dan Cara Membuatnya, https://ekspektasia.com/contoh-analisis-swot/ [Accessed, June 27, 2019]. 


\section{APPENDIX}

Appendix 1. The opportunities given to UK in Procurement General Planning 2014 to 2018

\begin{tabular}{|c|c|c|c|c|c|c|c|c|c|c|}
\hline \multirow{3}{*}{ Year } & \multicolumn{5}{|c|}{ Budget Ceiling } & \multicolumn{5}{|c|}{ Procurement package } \\
\hline & \multicolumn{2}{|c|}{ UK } & \multicolumn{2}{|c|}{ Non UK } & \multirow{2}{*}{$\begin{array}{c}\mathrm{Rp} \\
\text { (Trillion) } \\
\text { Total }\end{array}$} & \multicolumn{2}{|c|}{ UK } & \multicolumn{2}{|c|}{ Non UK } & \multirow[t]{2}{*}{ Total Package } \\
\hline & $\begin{array}{c}\mathrm{Rp} \\
\text { (Trillion) }\end{array}$ & $\%$ & $\begin{array}{c}\mathrm{Rp} \\
\text { (Trillion) }\end{array}$ & $\%$ & & Package & $\%$ & Package & $\%$ & \\
\hline 2014 & 94,00 & 32.87 & 192,00 & 67.13 & 286,00 & 543,905 & 84.17 & 102,318 & 15.83 & 646,223 \\
\hline 2015 & 129,50 & 23.69 & 417,20 & 76.31 & 546,70 & 696,870 & 58.56 & 493,239 & 41.44 & $1,190,109$ \\
\hline 2016 & 135,90 & 29.64 & 322,60 & 70.36 & 458,50 & 727,344 & 77.47 & 211,481 & 22.53 & 938,825 \\
\hline 2017 & 135,10 & 24.72 & 411,50 & 75.28 & 546,60 & 908,079 & 76.30 & 282,030 & 23.70 & $1,190,109$ \\
\hline 2018 & 136,80 & 23.29 & 450,70 & 76.71 & 587,50 & 952,715 & 75.77 & 304,615 & 24.23 & $1,257,330$ \\
\hline \multicolumn{2}{|c|}{$\begin{array}{c}\text { Average in } 5 \\
\text { years }\end{array}$} & 26.84 & & 73.16 & & & 74.45 & & 25.55 & \\
\hline
\end{tabular}

Appendix 2. Realization of E-Tendering 2014 to 2018

\begin{tabular}{|c|c|c|c|c|c|c|c|c|c|c|}
\hline \multirow{3}{*}{ Year } & \multicolumn{4}{|c|}{ Budget Ceiling } & \multicolumn{6}{|c|}{ Procurement package } \\
\hline & \multicolumn{2}{|c|}{ UK } & \multicolumn{2}{|c|}{ Non UK } & \multirow{2}{*}{$\begin{array}{c}\mathrm{Rp} \\
\text { (Trillion) } \\
\text { Total }\end{array}$} & \multicolumn{2}{|c|}{ UK } & \multirow{2}{*}{$\begin{array}{l}\text { Non UK } \\
\text { Package }\end{array}$} & \multicolumn{2}{|c|}{ Total Package } \\
\hline & $\begin{array}{c}\mathrm{Rp} \\
\text { (Trillion) }\end{array}$ & $\%$ & $\begin{array}{c}\mathrm{Rp} \\
\text { (Trillion) }\end{array}$ & $\%$ & & Package & $\%$ & & $\%$ & \\
\hline 2014 & 69,90 & 22.54 & 240,20 & 77.46 & 310,10 & 95,560 & 70.21 & 40,537 & 29.79 & 136,097 \\
\hline 2015 & 80,00 & 25.13 & 238,40 & 74.87 & 318,40 & 105,089 & 65.07 & 56,424 & 34.93 & 161,513 \\
\hline 2016 & 78,20 & 19.60 & 320,80 & 80.40 & 399,00 & 95,868 & 64.97 & 51,687 & 35.03 & 147,555 \\
\hline 2017 & 66,70 & 16.82 & 329,80 & 83.18 & 396,50 & 78,955 & 63.68 & 45,028 & 36.32 & 123,983 \\
\hline 2018 & 63,30 & 17.64 & 295,50 & 82,36 & 358,80 & 76,128 & 60.62 & 49,455 & 39.38 & 125,583 \\
\hline \multicolumn{2}{|c|}{$\begin{array}{c}\text { Average in } 5 \\
\text { years }\end{array}$} & 20.35 & & 79.65 & & & 64.91 & & 35.09 & \\
\hline \multicolumn{11}{|c|}{ Source: Summarized from LKPP, 2019} \\
\hline
\end{tabular}

Appendix 3. Number of Providers in Sistem Informasi Kinerja Penyedia (SIKAP)

\begin{tabular}{|c|c|c|c|c|c|c|c|}
\hline \multirow{2}{*}{ No. } & \multirow{2}{*}{ Sector Classification } & \multicolumn{3}{|c|}{ Year 2017} & \multicolumn{3}{|c|}{ Year 2018} \\
\hline & & Small & Non-small & Total & Small & Non-small & Total \\
\hline 1 & Civil & 9,808 & 42,498 & 52,306 & 29,905 & 8,041 & 37,946 \\
\hline 2 & Building & 8,205 & 28,117 & 36,322 & 26,417 & 7,837 & 34,254 \\
\hline 3 & Engineering & 2,028 & 7,058 & 9,086 & 8,998 & 2,307 & 11,305 \\
\hline 4 & Electrical Installation & 1,828 & 1,722 & 3,550 & 2,151 & 2,438 & 4,589 \\
\hline 5 & Specialist Consultation & 928 & 2,824 & 3,752 & 3,255 & 1,162 & 4,417 \\
\hline 6 & Specialist Executives & - & - & - & 3,255 & 1,162 & 4,417 \\
\hline 7 & Interior Design & 724 & 1,766 & 2,490 & 2,513 & 1,110 & 3,623 \\
\hline 8 & Architecture & 698 & 2,812 & 3,510 & 2,802 & 788 & 3,590 \\
\hline 9 & Mechanical Installation & 1,258 & 518 & 1,776 & 732 & 1,597 & 2,329 \\
\hline 10 & Other consultation & 766 & 1,182 & 1,948 & 1,061 & 810 & 1,871 \\
\hline 11 & Other executives & 66 & 28 & 94 & 25 & 77 & 102 \\
\hline 12 & Integrated & 58 & 2 & 60 & 1 & 70 & 71 \\
\hline 13 & Skill Executives & 6 & 18 & 24 & 11 & 3 & 14 \\
\hline & Total & 26,373 & 88,545 & 114,918 & 81,126 & 27,402 & 108,528 \\
\hline & $\%$ & 22.95 & 77.05 & 100 & 74.75 & 25.25 & 100 \\
\hline
\end{tabular}


The Empowerment of Small Enterprises in Construction Sector for Government Procurement of Goods and Services: Mandatory Study of Role and Risk (Mustofa Kamal and John Elim) 